\title{
"We Are Trained to Be Cynical": Arthur Koestler's The Call-Girls as a Campus Novel
}

\begin{abstract}
Arthur Koestler's The Call-Girls (1972) is, at present, mostly ignored, or if discussed, either dismissed wholesale, or approached only in terms of its role in the development of Koestler's political and philosophical thinking. The aim of this analysis is to show that it is possible to interpret the text as a highly specific campus novel, limited to a single setting: an academic conference. Although the conference's topic is "saving the world," the novel's characters neither achieve that aim, nor get any closer to a solution. Therefore, the book can be taken for a satirical treatment of the hypocrisy and futility of academic conferences, rather than a political plea, as previously understood.
\end{abstract}

Keywords

Arthur Koestler; campus novel; academic novel; fiction; conferences

Arthur Koestler's The Call-Girls ([1972] 1976) is the author's last novel, written slightly more than two decades after his previous one, The Age of Longing (1951), and one that has attracted little critical or academic attention. In fact, only one academic article is known to me to be dealing with its analysis, Naser Šečerović's (2009) "Koestlers Die Herren Call-Girls", and the novel is usually mentioned only in passing, if at all, by monographs devoted to the author. Wolfe Mays' (1973) Arthur Koestler, for example, merely acknowledges its existence at the end of the book, in its selected bibliography, but does not even mention it in the main text. The same is true of the volume of essays edited by Murray A. Sperber (1977), Arthur Koestler: A Collection of Critical Essays. Iain Hamilton's (1982) treatment is also very minimalistic, since it refuses to do more than introduce the basic facts of the 
circumstances of its creation, i.e. that it was written in instalments, parallel with The Case of the Midwife Toad (1971) and The Roots of Coincidence (1972), and that it was partially based on a scientific symposium Koestler organized in Alpbach three years earlier (Hamilton 1982: 357-359). And such general marginalization and dismissal is not only a phenomenon of what one could consider the immediate reception of the 1970s and 80s: Christian Buckard's (2004) "treatment" of the novel amounts to a single paragraph (319-20), Mihály Szívós' (2006) to a page (109), Michael Scammel's (2009) likewise (530-531).

The only exceptions to this general trend, beyond the already mentioned article, are Mark Levene (1985), who offers a lengthy treatment, which, however, rarely goes much further than providing a summary of the plot (133-43); David Cesarani (1998), not only because of his relatively more detailed discussion, but also because of some attempts at basic interpretation (500, 515-517); and László Márton (2006) who devoted a short, but insightful and clearly interpretive chapter to the novel (376-380).

The present essay attempts to show that this treatment is primarily the result of understanding the novel as a fictionalized plea for saving the world, and that such an interpretation is far from self-evident. This view, that the novel is a wake-up call to humanity, may, of course, be a result of Koestler's reputation as a political novelist: he is variously referred to as the "foremost political novelist of our day" (Brady 1946: 244), or as someone who "seems in the main to be aware of, and indeed to be obsessed by, the great cleavages in the political issues of our age" (Miller 1951: 12). William Phillips (1944) states that "while the political novel obviously is still far below the standards of the art novel, still, in the hands of Silone and Koestler, it has at least become a meaningful literary expression" (242; emphasis original). Likewise, John Atkins (1956) starts his foreword to his monograph on Koestler's writing by claiming that it "concentrates on Arthur Koestler as a political writer, which he primarily is" (7). Wolfe Mays (1973) stresses that Koestler was "one of the first [sic] to show, through his political essays and novels, the dilemma of the modern intellectual" (7). In Mark Levene's (1985) opinion, Koestler "left the most commanding of this century's political novels" (2), in fact, "[f]ew writers have affected men's thinking about politics so immediately and profoundly" (1). Thus, it is not surprising that many commentators of The Call-Girls would see it as yet another political novel, aiming at making a political statement, and possibly some change. Or, to quote Jenni Calder (1968), who goes even further, "Orwell and Koestler both had an intimate experience of the effects of propaganda and both condemned it for a variety of reasons. [...] Yet both writers remained compulsive, intense propagandists" (275). It is thus understandable that with such a mindset, a novel whose action takes place at a scientific conference devoted to the topic of saving humankind from self-destruction would be easily understood as one trying to save the world, or at least humanity from doom.

The present article, however, aims to show that this is not what the novel does. This is achieved through recontextualizing the text as a campus/academic novel 
that provides a satirical portrayal of academic conferences and their failure to achieve more than providing an outlet for the narcissistic tendencies of scholars. Although the threat of humanity's self-destruction is indeed tangible in the story, and the topic of the conference represented is, in fact, finding a way to avoid it, I aim to show that it only serves as a means to highlight the vanity and egotism of academics, and their inability and/or unwillingness to transcend the boundaries of their narrow specializations.

As I have already mentioned, there seems to be an almost complete agreement amongst those discussing The Call-Girls that it is a fictionalized plea to save the world, or at the very least a treatise on the chances of mankind's survival and possible ways that could be used to achieve it. The Virginia Quarterly Review's (1973) short note calls it a set of "[m]etaphysical disquisitions on the future of mankind" (civ; my emphasis); Eric Pace (1983), in his obituary in The New York Times, claims that "[i]n later years, much of Mr. Koestler's writing became more contemplative and philosophical, and he also gave much attention to science [...] 'The Call Girls' (1973), [sic] his first novel in two decades, discussed the odds of man's surviving the coming decades" (20; my emphasis). Although these are early discussions, many newer works follow the trend. Kirk Steen (2005), in his doctoral dissertation, sees the novel strikingly similarly: "By the early 1970s Koestler would explore various means to protect mankind from nuclear holocaust in his novel The Call Girls: a Tragi-Comedy in which participants in a scientific symposium offer various solutions to problems of antisocial behavior that ranged from operant conditioning to genetic modification of the human species" (12; my emphasis). For David Cesarani (1998), the novel "explicitly voices Koestler's political, almost messianic hopes" (500; my emphasis); and Michael Scammel follows suit when he claims that "[t]he best that could be said about it was that as the ventriloquist behind the speechifiers, Koestler got an opportunity to display his wide knowledge of a variety of scientific disciplines and to restate his diagnosis of man's ills in a more accessible form than in The Ghost in the Machine" (530; my emphasis). The same can be said of Mihály Szívós (2006) who states that "Koestler, just like previously in his essays, stresses here as well that with its nuclear weapons humanity entered an age in which it can destroy itself. The people at the conference, who are frequent participants of meetings of this kind, try to save humankind from itself, each with their own scientific repertoire"1 (109; my emphasis and translation).

Yet, a close reading effectively shows that the book does not comfortably fit the understanding that sees it as a fictionalized masterplan to save the world. The first reason is rather trivial: there is no single plan the text is supposed to present; in fact, quite the opposite is true, since the novel shows a wide range of competing plans, and none of them emerges victorious. The idea of "revolutionizing man's fate in the [...] womb" (Koestler [1972] 1976: 74) gets its fair share of pages, just as the view that "Western civilization in all its aspects [...] [has] to be destroyed in order to liberate society" (83), or that humankind could be saved by "creating outlets of violence on a mass scale" (98), alongside the suggestion that scientists 
should "find a paregoric which makes sailors immune against the siren's songs and the masses against the barking of politicians" (106) and "put it into the tapwater" (106). Similarly, the argument that all is possible to solve by "scientifically controlled schedules of positive and negative reinforcements" (115) gets the same amount of ground as another one that suggests that the solution is to go beyond the boundaries of known science, and investigate extra-sensory perception, since "it may change our outlook on the world" (125); and these are by far not even all of the competing plans presented. And although the conference organizer, Nikolai Borisovitch Solovief, indeed attempts to come up with an action plan, suggesting that humanity "cannot wait for another hundred thousand years, hoping for a favourable mutation to remedy [its] ills" (147), but it should rather act and "engineer that mutation [...] by biological methods" (147); this position, regardless of his role as organizer, remains his own, minority view that is not supported by the other participants. In fact, one of the contemporary reviews very poignantly summarizes this situation when it claims that "[ $t]$ hey decide nothing, disagree uniformly, and reach no definitive conclusions" (The Virginia Quarterly Review 1973: civ).

The conference is a failure in all possible senses. Not only do they not agree on the panacea for the problems facing mankind, or even on an action plan reaching one, they completely fail even to provide an outlet for academic research, at least from the perspective of posterity, and not in the sense of a momentary exchange of ideas. As Mark Levene (1985) writes, "[t]heir only unanimity is to suggest having the proceedings of the symposium published" (138), a truly minimal and certainly standard aim in the case of a conference; yet "even this modest voice of reason and the neocortex is smothered by the primitive" (138) when Miss Carey, who serves as a guinea pig for one of the conference's participants, "sets fire to the tapes" (138). And while Solovief has also wanted to send a letter to the President of the United States, nothing comes out of that either on the grounds that doing so would be "a political statement, and as such outside the terms of reference of this conference" (Koestler [1972] 1976: 155). That is, rather than proposing a plan for saving the world, the novel presents a plurality of opinions, and questions the very possibility of creating such a plan, as well as the ability of the academia to do so.

In fact, some of those commenting on the novel realized this, and understood the book in a less directly political way. Their interpretation usually sees the book as a didactical venture, presenting the cutting edge of science for readers who would not read scientific non-fiction, but are willing to read a novel. This view is shared by Mark Levene (1985), who sees The Call-Girls as "a survey of the ideas Koestler felt most compelled to attack or defend" (133), as well as Lorna Sage (1972), who considers it "a primary-coloured guide to the models of 'mind' we operate with" (1274). This interpretation, for the very reason that it acknowledges the whole scale of views present in the novel, is certainly based on a closer reading of the text. ${ }^{2}$

Yet, the very title of the novel itself should call for a different interpretation. After all, although the fictional conference is called "Approaches to Survival" (Koestler [1972] 1976: 26), the book itself is not. Instead, it is called The Call- 
Girls, and even if some may find this "a catchpenny title" (The Virginia Quarterly Review 1973: civ) which is "expressing unfair and exaggerated criticism"3 (Szívós 2006: 109; my translation), it certainly calls attention to the fact that the book's primary focus is provided by people, rather than theories. More specifically, scholars, as the text itself explains:

I am an academic call-girl. We are all call-girls in this bus. [...] You get a long distance telephone call from some professional busybody at some foundation or university - "sincerely hope you can fit it into your schedule - it will be a privilege to have you with us - return fare economy-class and a modest honorarium of..." (Koestler [1972] 1976: 21)

To be completely fair, it is important to mention that this fact (i.e. that the book can be seen as a text about academics rather than about ways to save the world) was noticed by some, even if a minority, of those who commented on it. Iain Hamilton (1982) apostrophizes the story as "a satirical-tragical-farcical novel about the scholars travelling [...] from symposium to symposium" (357), while László Márton (2006) also sees it as a "novel bordering on parody"4 (378), in which Koestler "perceives his own performance with biting self-irony and at the same time observes his colleagues [ $=$ scientists] with an indulgent smile"5 (378), and where the title is a reference to those "scientists who present, or one could say sell, the same thesis, conference after conference in more-or-less different packaging" (379). And Bernard Avishai (2003) also sees the book as a "spoof on the international academic circuit, in which writers and scholars sell their talk [...] for a week in Switzerland"7 (234).

However, if The Call-Girls is indeed a novel about academics and their antics, it is logical to suppose that it could be considered a campus novel, which was defined by John E. Kramer (1981) as a fictional story which "incorporates an institution of higher learning as a crucial part of its total setting and [...] includes, among its principal characters, graduate or undergraduate students, faculty members, administrators, and/or other academic personnel" (ix). While this definition is admittedly ill-fitting for Koestler's text, since the story does not take place at a college, but at a conference center, and the students are completely missing as well, this should not be an insurmountable problem. As Robert F. Scott (2004) explains, "the academic novel is a vital and aesthetically rich literary genre that has continually evolved in order to meet the demands of its large and ever-expanding readership" (82). In other words, the genre is neither rigid, nor unchanging, and the switching of focus from the university campus to the academic conference fits into its general development. That is, rather than being a case of basic incompatibility, this different location is, in fact, in harmony both with the genre's organic development, and the change of academic life itself:

Technical innovations such as Xerox machines, direct long-distance dialing [...] and jet trav$\mathrm{el}$ as well as the funding of research projects through foundations have resulted in fundamental changes in the system of scholarly communication and in the way research is conducted 
$[\ldots]$ Hence the international conference rather than the individual campus and its library are the proper habitat for the scholar of the eighties. ${ }^{8}$ (Mews 1989: 715)

While Sigfried Mews' formulation might be overly strong and unsupported by data, as a large portion of novels published during and since the 1980s have kept the campus as their location, he is right in pointing out that the academic novel has reached beyond the university campus, some works leaving it behind completely, others extending their fictional universe beyond its boundaries. This should not come as a surprise since, as Sanford Pinsker (1999) stresses, even in academic novels taking place at a campus, one cannot help to notice that they are examples of a genre "in which professors are hardly ever seen preparing lectures, teaching classes, or grading papers" (442). Siegfried Mews (1989) offers a canonized academic novel as his example of the academic novel leaving university campuses behind: David Lodge's Small World: An Academic Romance (1984), taking place mainly at conferences. One could also mention Malcolm Bradbury's "novella Cuts (1987) which [...] explores, with humour, but with an equal sense of doom, the traumatic experience of a faculty member who is cut off from his environment by economic necessity and unwillingly enters the world of television and hard finance" (Petraşcu 2015: 63). Jeffrey J. Williams (2012) categorizes Saul Bellow's Herzog (1964) as an academic novel, stressing that although the protagonist "has left his academic job, $[\ldots]$ it is essential to his portrait that he is a professor" (Williams 2012: 564), and the book in fact "augurs the new professor arising in the 1960s, devoted to research" (564). In other words, moving the focus of the academic novel away from the university campus is neither unique to Koestler's novel, nor something that contradicts the genre's development.

Turning now to the issue of the lack of students, their presence or absence is also not as central to the genre, as one would think. As Robert F. Scott (2004) explains, regardless of a general belief to the contrary, "students do not often figure prominently in academic novels" (84). In fact, on the basis of his extensive research of such novels published at or around the millennium, he goes as far as to suggest the following:

Such an absence is especially striking given the fact that the primary responsibility of most professors is to teach. Yet, in the vast majority of academic novels, the overriding implication seems to be that teaching is not an essential component of higher education. That is, not only do campus novels rarely depict their protagonists in the classroom, but these figures also seldom discuss their actual teaching experiences. (84)

That is to say, the lack of students is much more of an expected central characteristic feature of the genre as it is today, than a divergence from it. Although the location being an international conference certainly makes the fact more credible and natural, such an absence would be feasible even without it.

Nevertheless, one certainly feels somewhat uncertain about using the term 'campus novel' for a book that has nothing to do with a campus, nor even stu- 
dents. Noticeably, even Scott himself is using an alternative expression. Changing the term to 'academic novel', without any specifications, however, might also lead to causing more confusion, rather than making the situation clearer. After all, it could lead to questions about the relation of the two terms to each other (i.e. are they exclusive categories or is 'academic' a bigger category) or even relevance (i.e. has the evolution of the genre made the term 'campus novel' outdated and/or ill-fitting). While solving theoretical debates about the terminology of novels dealing with academic topics and/or featuring academics as characters is not something this article aims to achieve, it nevertheless seems necessary to stick to one particular term and specify what exactly is meant by it. Because of this, I suggest following Jeffrey J. Williams' (2012) bifurcation of the genre:

\begin{abstract}
I think it is useful to distinguish among novels that center on students and those that center on professors. I would call the former "campus novels" because they tend to revolve around campus life and present young adult comedies or dramas, most frequently coming-of-age narratives. The latter I would designate "academic novels" because they feature those who work as academics, although the action is rarely confined to a campus, and they portray adult predicaments in marriage and home as well as the workplace, most familiarly yielding midlife crisis plots. (561-562)
\end{abstract}

Given the above distinction, The Call-Girls is clearly an academic novel because of its focus on academics, as well as the action taking place off-campus, and, as it will be shown later, also because of its portrayal of "adult predicaments in marriage" (562) and the presence of "mid-life crisis" (562).

Beyond those mentioned by Williams (2012), Robert F. Scott (2004) adds a set of further features that are typical of academic novels. His text emphasizes "the colorful, often neurotic personalities who inhabit academia" (82), as well as the omnipresence of "ideological rivalries which thrive in campus communities" (82) and finishes the list with the mentioning of "sexual adventures of all types" (82). These are the characteristics, then, that I am going to show in The CallGirls, along with the already mentioned issues of "adult predicaments in marriage" (Williams 2012: 562) and the presence of midlife crises (562).

Starting with the issue of sexual adventures, one certainly finds a wide variety in the novel. Dr Cesare Valenti, for example, is not only "a wizard among neurosurgeons, with a Nobel prize to his name" (Koestler [1972] 1976: 29), but also, and just as importantly, "the greatest Lolita-chaser alive" (29), who is "strikingly handsome, with his dark, insinuating eyes and faintly ironic expression" (58), and who has "a pleasantly melodious voice" (58). More disconcertingly, he also does not refrain from experimenting with inducing sexual pleasure in patients through radio simulation of an electrode implanted in their brain:

Needles implanted in the so-called pleasure centres of the hypothalamus [gave] patients a feeling of euphoria or of erotic arousal which sometimes ended in the psychic equivalent 
of an orgasm. [...] She watched him adjusting a dial. "Ah," she sighed. "This feels lovely. It must be the naughty needle. Naughty, naughty. You are doing it..." $(134,137)$

Yet, with all his strange experiments in sexual mind control, his great looks and his tendency to chase young girls, Dr Valenti remains one of those who do not use the conference as an outlet to engage in sex.

Quite in contrast to Dr Harriet Epsom, an ethologist, who not only flirts with the aim to make the only priest present at the conference blush (20), gossips in whispers about various participants $(21,68)$, but goes much further than that and sleeps with two different people present, the first of whom is the bus driver:

From the basement of the building came radio music - the Blue Danube. That must be Gustav, the driver with the waxed moustache. He did not look unpromising - she and Helen had exchanged guesses about the quality and dimensions of his equipment. [...] Five minutes later she entered Gustav's room, without knocking and without her stick, in her scarlet dressing-gown. [...] Gustav was lying in his bed, sunburnt torso uncovered, smoking. He did not look the least bit surprised. He would have preferred the dark one with the shaven neck, but one couldn't always choose, and this one had her points too - haunches like a mare. "Komm here please," he said politely, putting out first his cigarette, then the light. (68)

While the scene certainly has its moments of humor on its own, it also serves as a counterpoint to the other event of this kind that involves Dr Epsom. As the two extracts show, her relationship to sexuality is certainly more complex than one would expect at first sight. She is not simply another example of the sex starved, single, heterosexual academic who tries to flee into fleeting one-night stands as a result of not having enough time for a more lasting connection:

There was a knock at the door and Helen Porter walked, or rather floated in, in a cloud of scent. She wore semi-see-through purple pyjamas and her neck was freshly shaven. She made straight for Harriet's bed and covered herself with the voluptuous eiderdown.

"At last," said Harriet, calmly completing her restoration work. "Couldn't you think of it earlier?"

"And what about your gamekeeper with the waxed moustache?"

"That was a mistake," Harriet admitted bravely. "He hurried as if he had to catch a train.

Before you could say Jack Robinson it was all over." (158)

Not only does the scene complicate the issue of Dr Epsom's sexual orientation, but also shows that with all her interests in the bus driver (68) and the priest (20-21), she may have a long lasting, possibly open, relationship with Helen Porter, the butch-looking Kleinian psychoanalyst, and possibly this is what the latter one refers to when she says that "Harriet [...] brought me along as a sort of lady's companion" (29).

But the two ladies are not the only ones whose sexuality is beyond the confines of heterosexuality. The poet, Sir Evelyn Blood, is openly homosexual: "I am 
queer as a kipper" (64) he proudly announces at lunch, while he tries to find out if the Catholic priest, Tony Caspari, is a virgin (63) and if he is hetero- or homosexual (64). In fact, it is not completely impossible that just like Harriet Epsom, he is also interested in him, considering that he tries to convince him to accompany him to the village where "[t]here is supposed to be some wrestling competition in the village for those juicy farm boys" (64).

Where the issue of "sexual adventures" (Scott 2004: 82) gets combined with "adult predicaments in marriage" (Williams 2012: 562) is the situation of the conference organizer, Nikolai Borisovitch Solovief, and his wife, Claire. On the one hand, they are each other's biggest support, and they truly care about the worries, problems and feelings of the other one. Claire knows "as a fact [...] that Niko infallibly sense[s] when she need[s] him, whether he [is] at the other end of a crowded room or at a conference on the other side of the Atlantic" (Koestler [1972] 1976: 31). The amount of respect and care Nikolai has for Claire is also shown by his "pretending to be asleep, to give Claire the illusion of privacy" (37) when she is writing a letter he thinks he is not supposed to know about, and by his trying to protect her from knowing that "the results of [his] last [medical] tests" (38) suggested the possibility that he might "suddenly vanish from the scene" (38). Not to mention his genuine pleasure in the thought that should such an event happen, there would be someone who "could perhaps fill at least a fraction of the void for Claire" (38) and his constant "glancing sideways at Claire, worried about the possibility of an infection" (146) after she was injured in an attack with a knitting needle (143).

And it is not a one-sided emotion, either. Apparently, just like her husband, Claire also has the ability to feel the moments when Nikolai needs her:

\footnotetext{
She saw that Nikolai was seated between Harriet Epsom and Helen Porter; the fourth chair at their table was empty. Although he had two women at his sides, one of them confoundedly attractive, Claire thought, he had an absent look. [...] Nikolai was molding a piece of bread into a shrunken skull with his long, powerful fingers. [...] She caught his eye and decided to join his table instead of playing hostess somewhere else. (34)
}

Just as mentioned in the extract, her myriad ways of supporting him include "playing hostess" (34) for the whole conference, and more than that: she also uses her skills of diplomacy to avoid conflicts and unpleasant situations between participants, techniques learnt from her father who "was in the Foreign Service, but [whose] real job was to act as a diplomatic chucker-out at receptions when people stayed too long" (28-29), and also has administrative duties, acting as conference secretary (49), and when needed, even takes over the responsibility from Miss Carey to operate the tape recorder $(135,144)$. She shares her husband's feelings, once even being on the verge of crying because of the turns of events at the conference (69).

The two of them also function as a proper couple: with all their duties as secretary and chair of the conference respectively, she and Nikolai nevertheless spend a lot 
of time together, discussing the papers, the future of the world, and various other topics important for Nikolai, or both of them (39-40, 71-72, 78-82, 116-117, $127-128,161-162,164-165)$. They go for a walk in the village (78), and regardless of being central to the smooth running of the conference, they risk "playing truant from a meal at the Kongresshaus" (116). In each other's company, they are even able to leave their worries behind to allow them to feel "as if on a holiday" (117), and ultimately, even though the conference ends as a failure, they decide "to stay on for another day and walk in the mountains now that the tourists [have] gone" (164). What is more, although admittedly there was a pause of all such activities for a longer time, they also restart their sexual life at the conference:

\footnotetext{
"I think I shall shack up with you," he said, transferring his huge bulk with surprising agility under the eiderdown.

"Nice," said Claire. "But you don't want to feel tired tomorrow."

"I can apologize in my opening address. 'Ladies and gentlemen, I hope you will sympathize if I am a little worn out by the legitimate demands of my seductive wife."”

"That will do nicely to start the discussion," Claire said soberly but with a slightly throaty voice. It was their first resumption of what Burch's textbooks called species-specific mating behaviour [...] and it went very well. Perhaps it was the effect of the Höhenluft.

"I won't go back home," said Nikolai, meaning his own bed.

"Don't," said Claire. (39-40)
}

Yet, this strong support, understanding, as well as their functioning as a couple at various levels, including the sexual one, is just one side of their relationship. What shows that it is indeed a mature relationship is not only these features, but primarily the fact that it works this way even though Claire has a lover, to whom she is writing long letters, and even though Nikolai and her live in an open relationship:

Through the open window he could see in the moonlight the intent curve of her back as she wrote her letter; he assumed that she was writing to Guido, and felt a twinge of jealousy. They had never seriously discussed Guido, nor Nikolai's or Claire's earlier episodic affairs; he had always maintained that strict monogamy was only for saints. [...] They had learnt to tolerate each other's occasional peccadilloes as a kind of protection money paid to Aphrodite, the devious bitch. (37-8)

What shows best that this is truly a mature relationship and not one built on dishonesty where the partners try to secretly have affairs behind each other's backs, and where if the other one finds out, they also try to keep it secret is that although they admittedly do not discuss partners in detail, they are frank and open about them:

"Oh dear, you won't start working now?" she said, neatly arranging her writing things in a drawer. 
"You have been working until now," Nikolai said meaningfully.

"I have been writing to caro Guido," Claire said. "He feels very lonely, having temporarily lost a valuable member of his audience. Are you making notes for tomorrow?" (39)

Not to mention that she writes to the said Guido "straight in front of his nose" (39), and the two of them make love a few minutes later (40).

Turning to the issue of mid-life crises, the book demonstrably features them, as well. One of the most striking cases is the already mentioned Dr Harriet Epsom. While Mark Levene (1985) claims that the reason she engages in one-night stands and tries to seduce people is because "she is incapable of translating [her] understanding" (139) of how people work "into public action" (139), and thus her "only answer to the issues raised by her own work and by the discussions at the conference is to seek out some Alpine sex" (139), I think her case much more easily lends itself to a different interpretation. In my reading, the spheres of personal and private life remain distinct for her, and her crisis is of a purely personal nature: it is related to her looks, or rather to losing them, and in a more general sense to aging as such.

That she must have been a stunning beauty and still has a body that has attractive features is stressed at many points, at first early in the story, when she gets out of the bus taking the participants to the conference:

H. E. herself looked certainly neither dowdy nor tired. She was leaning on a heavy walking stick with a rubber end, and wore a mini-skirt of some exotic material, revealing a pair of formidable thighs, made more fascinating by the blue veins wending their way through valleys of gooseflesh. (Koestler [1972] 1976: 27)

A few pages later, the reader finds out through a comment by Claire that the already mentioned part was certainly not the only one that might grab the attention of anyone sexually attracted to women when she remarks that "Harriet's bosom could accommodate at least four souls" (35). Likewise, Harriet herself admits that her face, at least if made up, does "not look all that old and all that bad" (68), while Gustav, the bus driver also comments positively on her looks, in his rather hoarse way: "this one ha[s] her points too - haunches like a mare" (68).

Yet, that it is only a shadow of what there used to be, and that even what remains is rapidly fading, is made quite apparent, and so is the fact that this is emotionally taxing for Dr Epsom. For one, she is using "a heavy walking stick with a rubber end" (27) to walk, a fact that at least she herself considers as a feature taxing on her looks, since when she seduces Gustav, the bus driver, she makes a point to enter his room "without her stick" (68). Similarly, although she eventually claims that she does "not look all that old and all that bad" (68), this is markedly and emphatically only after she "washed her face in cold water and made it up in front of the mirror" (68); before that, it is described as a "big blotchy" (68) one. At another point, the difference between her made up and natural face is described even more brutally: "Harriet Epsom was sitting in front 
of her dressing-table, taking off her make-up with the thoroughness of a picturerestorer cleaning an antique landscape" (158). That she is also probably overweight turns out in her scene with the bus driver:

"Komm here please," he said politely, putting out first his cigarette, then the light. A moment later he remembered that scarifying experience on the Schafberg when he lay buried under an avalanche. (68)

But probably nothing shows better that Harriet Epsom really encounters a crisis because of her aging and her deteriorating looks than the fact that at a certain moment she ends up crying "because she [feels] too old and ugly to seduce blueeyed Tony, for whom she [has] developed a violent, aching crush" (68).

And Dr Harriet Epsom is by no means the only character who experiences a life crisis. Nikolai Borisovitch Solovief is probably an even clearer case, although calling it a midlife crisis might not be very precise, since in his case, it is a rather protracted one, one that is getting progressively worse and worse. It starts during his university years when he believes, "with almost religious fervour, that the mystery of the universe [is] contained in the equations which [govern] the ballet of the tiny particles inside the atom, and in the Wagnerian grand opera performed by comets, stars and galaxies" (44), although at that time "leading physicists everywhere [are] abandoning that dream" (44). This contradiction remains with him at the time of his discovery of a new particle "which br[ings] him the Nobel Prize" (45), and in which he cannot believe:

He could never take himself, nor the myatron [ $=$ the particle he had discovered], quite seriously. He had predicted its existence and photographed its track, but he could not convince himself of its reality. Or rather, he could not persuade himself of the Reality of the scientist's reality. [...] The French had an expression: "c'est pas sérieux..." (45; emphasis original)

This inability to believe in the very reality of his own endeavors later gets coupled with guilt felt due to "the poise of the detached scientist" (46) assumed at a time when the Nazis kill his girlfriend's father and cause her suicide, as well as for his active role in developing the nuclear bomb (47). By this time, his fame "only add[s] to his discouragement" (47), and while speaking with colleagues, he "detect[s] in [their] voice an echo of his own mood of despair" (47). In the two decades of his life immediately preceding the action of the novel, this reaches a level that amongst others forces him to change radically his research interests and keeps him on the borderline of ending it all:

What kept him going through his forties and fifties was partly Claire and the two children, partly his new field of research: the use of radioactive isotopes in the therapy of malignant diseases. He devised several improvements of existing techniques - for he could not help drawing a spark from whatever his fingers touched - but none of them represented a major breakthrough. (47) 
While this all may already sound like a fairly convincing case of a midlife crisis, it gets even worse. As a reaction to his loss of belief, he ends up with "a habit of hunching up his powerful shoulders as if carrying an invisible weight" (48) and experiences a "growing depression" (48). And while Harriet Epsom's ability to cope with her crisis is an open question, Solovief's is not: by the end of the novel he is hardly more than "a sick, ageing man" (157) with "nagging pains" (161).

While even the previous cases might have already convinced one that the novel is full of "the colorful, often neurotic personalities who inhabit academia" (Scott 2004: 82), considering their wide range of sexual behavior and their mid-life crises, there are certainly more features of the already mentioned characters that might earn them labels of eccentricity and color, not to mention the range of other scholars who might deserve such a categorization. Solovief, for example, is not only fighting a losing battle against cancer and his personal crisis, but is also somebody who regularly plays with his food, "molding a piece of bread into a shrunken skull with his long, powerful fingers" (Koestler [1972] 1976: 34) or "using a delicious local bread-roll to model a creature that looked like a dinosaur" (88). He is also somebody who, regardless of his melancholy and potential depression, is often "very conspiratorial and rather schoolboyish" (72), "an incurable sensualist" (38), and somebody who inevitably attracts female company. In Harriet Epsom's words, it is "Niko's harem" (34), which, in her opinion, forms thanks to the fact that "[w]omen don't listen to Niko's voice with their ears - it goes straight to their uterus" (50). Further, he was "a musical prodigy" (41), giving his first public concert at fifteen (41), and who, after losing one of his fingers thanks to his experiments with radiation "trained himself to play the piano with nine fingers" (48).

But the protagonist, Solovief, is by far not the only character for whom the label of colorfully eccentric academic might fit. For one, one could recall the blunt exhibitionist, Otto von Halder: "His wild white mane bobbing high above the madding crowd, every inch a King Lear, he was approaching them with his inimitable gait, a combination between goose-stepping and deer stalking. One could not help glancing at his legs - moccasins, tartan stockings, hair, knobbly knees, more hair, khaki shorts, in that order" (28), who, in Claire Solovief's informed opinion, is "not as silly as he sounds" (29) and his behavior is nothing but an "enfant terrible act" (29; italics original), sporting "rude manners and a golden boy-scout heart" (55). What is more, in addition to the already strong contradiction between the exterior pose consisting of majestic looks and a "carefully dishevelled white mane" (55; italics mine), and the interior of his good heart and honest intentions, he also used to be a "member of the Nazi Party - everybody knows it, but pretends not to know" (101), while at the same time he "also sheltered a couple of Jewish colleagues, risking his neck" (101).

Another likely candidate would be Bruno Kaletski, "winner of the Nobel Prize for Peace" (49), who arrives late at the conference, but probably "the only reason for his being late [is] the need to impress on the others what a busy and important person he [is]" (50), since he shares at least one trait with Otto von Halder: he is 
"also an incurable show-off" (50). In addition, he is always "determined [...] to hog the discussion" (54), "talk non-stop" (54) and "keep interrupting the speakers to cross-examine them" (54). At the same time, he is more than an exhibitionist, since in his scientific judgments he is mostly "dead right" (55), and even when they are based only on instinct, "often as not his hunch [has] something to recommend it" (55). Further, he is an example of an eternal prodigy, having been "a Wunderkind at the age of five" (55) and being "still an infant prodigy at the age of seventy-five" (55): then for "being intellectually so far in advance of his age" (55), and now for "being so much younger than his age" (55). And yet, with all his achievements, his geniality and his tendency to monopolize all discussions, his moments of confusion would at times make him "look quite endearing" (62). What is more, he is both aware of his problematically dominant style of discussion and also suffers because of it: "Bruno Kaletski wept, interrupted by convulsive hiccoughs, because he had done it again, and made himself loathsome to all with his verbal diarrhea though he had sworn never, never to do it again" (68). Finally, with all his real political influence, scientific stature, achievements and knowledge, he is a character who is "difficult to take seriously" (88). And while it would be easy to continue the list of such characters beyond Nikolai Solovief, Otto von Halder and Bruno Kaletski, these three examples suffice to show that the novel indeed features what Robert F. Scott (2004) calls "the colorful, often neurotic personalities who inhabit academia" (82).

Instead, I will focus on the last characteristic feature of the academic novel that he identified: the "ideological rivalries which thrive in [academic] communities" (82). This issue, in fact, appears very early in The Call-Girls. While still sitting on the bus taking the participants to the congress center housing the conference, Tony Caspari is reading the venue's brochure:

The young friar was also studying the leaflet. "One wonders," he remarked, "why the European Psychiatrists and the World Psychiatrists can't get together when they are discussing the same subject."

"Different schools," Burch replied gruffly. "Analytical orientation versus pharmacological orientation. They are at each other's throats."

"I remember now," Tony said eagerly. "I read how they keep excommunicating each other. What a pity." (Koestler [1972] 1976: 19)

Of course, similar debates are not only observed from a distance by the participants, but they also engage in debates of the same kind. The presence of Helen Porter, a Kleinian psychoanalyst at the conference, for example, irritates Horace Wyndham, even though she is only an observer:

"I am not a Participant," said Dr Porter. "Harriet just brought me along as a sort of lady's companion."

"Poor little you," said Clair. "Nikolai may relent and admit you to one of the sessions as a Discussant." 
"I protest, protest, protest," said Horace Wyndham, all dimples and titters, spreading his palms. "I don't wish to be torn into little pieces by a Kleinian." (29)

And he is not the only one who has issues with Kleinian psychoanalysis, either. Professor Burch likewise considers even Dr Porter's mere presence as an insult, and he leaves no doubt as to his views on the school of thought she belongs to:

"I did not know that a Kleinian had been invited," said Burch. "Had I known, I would have had to reconsider my acceptance. Solovief has the most peculiar ideas."

"She hasn't been invited. She's only a kind of camp-follower brought by Harriet."

"Why do you dislike Kleinians?" asked Tony. "Do you dislike them in particular or do you dislike all Freudians in general?"

"I wouldn't know the distinction," said Burch, peering sharply over his gold-rimmed halflenses, "any more than I am interested in the disputes between Jansenites and Jesuits. I happen to be a scientist and as such concerned with observable behavior. Show me a slice of your super-ego under the microscope and I will believe in its existence." (30)

That such a view springs more from the speaker's prejudices and herd instincts than one of them being right and the other mistaken is shown by Burch's further ideological debate with Nikolai Solovief. While Burch is a psychologist and Solovief is a physicist, instead of the two of them agreeing on empirical materialism being the only acceptable approach to discovery, they end up on opposite platforms:

"I would rather believe in little green men from Venus, travelling in flying teapots, than in a mind or soul which is not located in space and time and has no measurable temperature, or weight." Burch spoke with some heat. To Tony he had been condescending; in Solovief's presence he became aggressive.

"In our laboratories," Solovief said, pointing an accusing finger at Burch, "we deal with the elementary particles of matter, electrons, positrons, neutrinos and what-have-you, some of which possess no weight, nor mass, nor any precise location in space."

"We have all heard about those wonders. There has been no lack of publicity. So what do they prove?"

"They prove that materialism is vieux jeux, a century out of date. Only you psychologists believe in it. We know that the behaviour of an electron is not completely determined by the laws of physics. You believe that the behaviour of a human being is completely determined by the laws of physics. Electrons are unpredictable, people are predictable. And you call this psychology." (31-32)

Similar heated and angry debates keep reappearing throughout the novel. One could mention Sir Evelyn Blood's fight with Raymond Petitjacques, leading to verbal fireworks along the line of the following: "What do you call this philosophy? Merdology? To my mind you are nothing but a clown" (67), "Pure jabberwocky. [...] the biggest hoax since the Piltdown skull" (66). Another such 
tense exchange of opinions emerges between Horace Wyndham, Raymond Petijacques, Otto von Halder and Harriet Epsom (76-78). And the list could easily be continued. In fact, these ideological fights and the forming of competing camps go so far that even beyond the struggle of a multitude of schools, approaches, opinions and fetishes, the very conference itself divides itself into two opposing formations:

\footnotetext{
"Thank you, Professor Burch," Wyndham said; and later on it was agreed that this had been the moment when the symposium began to divide into two camps. However, the only overt signs of the incipient split were some clearings of throat and shufflings of feet. All took it for granted that Burch - as could be expected - had made a monumental ass of himself. The majority - later on to be referred to as the Nikosians - thought what a clever bastard Solovief was to invite the most extreme, rigid and orthodox representative of a school of thought to which he was known to be passionately opposed. (57)
}

To sum up, Arthur Koestler's The Call-Girls visibly features all the characteristics of an academic novel, as identified by Robert F. Scott (2004) and Jeffrey J. Williams (2012): it is full of "colorful, often neurotic personalities" (Scott 2004: 82 ), "sexual adventures of all types" (82), "ideological rivalries" (82), spiced with the characters' midlife crises and struggle with "adult predicaments in marriage" (Williams 2012: 562). Its humor and criticism of academic conferences and their participants demonstrably makes the novel a prime example of the academic novel, rather than a recipe for saving the world, or a fictional vehicle for disseminating scientific theories.

This has significant consequences both for the novel's reception and the understanding of Arthur Koestler's fiction in general. As I have illustrated above, there has been a long tradition of categorizing and attempting to interpret Koestler's novels as examples of political fiction. Yet, as this article has demonstrated, The Call-Girls is more of a campus novel than a political novel. That this is the case raises the question if the rest of his fiction can be as easily and unambiguously labeled political fiction as the Koestler-reception of the last eight decades has done. While many, if not all, of those books can be demonstrably linked to specific political dilemmas and causes, many of them would just as comfortably fit the labels of other genres. His The Gladiators (1939), focusing on the Spartacus-revolt, is visibly a historical novel. In his Arrival and Departure (1943), most of the text is devoted to the main character's psychoanalysis, and it could thus warrant its discussion as an example of the psychological novel. Thieves in the Night (1946) shows the development of its protagonist into a terrorist, and it could thus be considered a negative Bildungsroman. The list would be easy to continue.

As far as the book itself is considered, given the almost complete lack of analyses, any discussion of it is, by its mere existence, a welcome addition. Beyond that, my interpretation could show that it is feasibly more than an example of didactic fiction aiming either at stopping humanity destroying itself or, alternatively, educating the reader about the state of the art in 1970s natural science. 
Thus, by situating the book within the genre of the academic novel and disproving the idea of it being a simplistic and manipulative narrative, this article also creates some ground for its further academic discussion.

\section{Notes}

1 "Koestler, mint már korábban esszékben is, itt is érzékelteti, hogy az atomfegyverrel az emberiség abba a korba lépett, melyben már saját magát is elpusztíthatja. A konferencia résztvevői, akik gyakori szereplői ilyen összejöveteleknek, az emberiséget akarják megmenteni önmagától, ki-ki a saját eszközkészletével."

2 It is interesting to note that Koestler himself shared this view, at least partially. In a diary entry, Cynthia, his wife, notes the following: "C-Girls. [...] It was a tragi-comedy \& nobody had done a satyre [sic] on the state of knowledge since Flaubert with Bouvard et Pécuchet \& Voltaire with Candide. It was a panoramic overall view of the state of knowledge" (The Koestler Archive, MS2305, diary labeled “Aug. - Nov. 1971”, December 3, 1971). (Koestler had stopped writing his own diaries decades earlier and had made her take extensive notes of the day's events, as well as his thoughts and ideas, Koestler often specifically dictating parts of the entries.) At the same time, his own view certainly differs from those who might suggest taking the novel as a plea to save the world: "A[rthur] said Anthony was naïve in thinking that he, Arthur, could influence people with his books. That wasn't true nowadays - you can only influence a very small per cent" (November 9, 1971). He certainly must have had several interrelated issues in mind, as elsewhere he noted to Cynthia that the "problem is to find a plot to illustrate the theme, the madness of man" (The Koestler Archive, MS2305, diary labeled "Dec. 68 - Dec. 69", February 7, 1968); and at another occasion, while working on the novel, he discussed the futility of conferences with a guest, explicitly asking Cynthia to make sure this idea would be available for later reference: "This came up because she \& A discussed the lack of communication at symposiums - everybody being only interested in what he himself has to say. [...] He told me to put this down in the diary" (The Koestler Archive, MS2305, diary labeled "Dec '69 - Nov '70 DIARY", April 5, 1970).

"igazságtalan és túlzó kritikát fejez ki".

"paródiába hajló regény".

"Maró öngúnnyal tekint saját szereplésére és egyben elnéző mosollyal szemléli társait".

“azokra a [...] tudósokra utal, akik egyik konferenciáról a másikra tartva ugyanazt a tételt adják elö, mondhatni adják el, többé-kevésbé különböző csomagolásban”.

He is strikingly wrong, however, about the location of the conference. It is not in Switzerland, but in Austria.

8 Or, in fact, already the early seventies if Koestler's novel is to be believed.

\section{Acknowledgement}

The writing of this article was supported by a Type B Bursary of the European Society for the Study of English, the research project OP VVV CZ.02.2.69/0.0/0 .0/16_027/0008493: "MOTUL: International Mobility of Researchers at TUL," the research grant SGS-FP-TUL 17/2016: "Unduly Forgotten: Arthur Koestler's Late Fiction," as well as by the Mobility Fund of the Technical University of Liberec. 


\section{References}

Atkins, John (1956) Arthur Koestler. London: Neville Spearman.

Avishai, Bernard (2003) Arthur Koestler: The consolations of communism. Partisan Review 70 (2), 228-244.

Bellow, Saul (1964) Herzog. New York: Viking.

Bradbury, Malcolm (1987) Cuts. London: Hutchinson.

Brady, Charles A. (1946) Bren guns in the Holy Land. America, November 30, 243-244.

Buckard, Christian (2004) Arthur Koestler: Ein extremes Leben 1905-1983. Munich: C. H. Beck.

Calder, Jenni (1968) Chronicles of Conscience: A Study of George Orwell and Arthur Koestler. London: Secker \& Warburg.

Cesarani, David (1998) Arthur Koestler: The Homeless Mind. London: William Heinemann.

Hamilton, Iain (1982) Koestler: A Biography. London: Secker \& Warburg.

Koestler, Arthur (1939) The Gladiators. London: Jonathan Cape.

Koestler, Arthur (1943) Arrival and Departure. New York: Macmillan.

Koestler, Arthur (1946) Thieves in the Night. New York: Macmillan.

Koestler, Arthur (1951) The Age of Longing. New York: Macmillan.

Koestler, Arthur (1971) The Case of the Midwife Toad. London: Hutchinson.

Koestler, Arthur ([1972] 1976) The Call-Girls: A Tragi-Comedy with Prologue and Epilogue. London: Pan Books.

Koestler, Arthur (1972) The Roots of Coincidence. London: Hutchinson.

Kramer, John E. (1981) The American College Novel: An Annotated Bibliography. New York: Garland.

Levene, Mark (1985) Arthur Koestler. London: Oswald Wolff.

Lodge, David (1984) Small World: An Academic Romance. London: Secker \& Warburg.

Márton, László (2006) Koestler, a lázadó. Budapest: Pallas.

Mays, Wolfe (1973) Arthur Koestler. Guildford: Lutterworth Press.

Mews, Siegfried (1989) The professor's novel: David Lodge's Small World. Modern Language Notes 104 (3), 713-726.

Miller, Emanuel (1951) Koestler's satire. Jewish Chronicle, May 4, 12.

Pace, Eric (1983) Arthur Koestler and wife suicides in London. The New York Times, March 4, 1, 20.

Petraşcu, Mirela (2015) Local and global impact zones in the campus novel: Showcasing Malcolm Bradbury's Cuts. Transilvania 2015 (5), 62-70.

Phillips, William (1944) Koestler and the political novel. Nation, August 26, 241-242.

Pinsker, Sanford (1999) Who cares if Roger Ackroyd gets tenure? Partisan Review 66 (3), 439-452.

Sage, Lorna (1972) Mental models. Times Literary Supplement, October 27, 1274.

Scammell, Michael (2009) Koestler: The Literary and Political Odyssey of a Twentieth Century Skeptic. New York: Random House.

Scott, Robert F. (2004) It's a small world, after all: Assessing the contemporary campus novel. Journal of the Midwest Modern Language Association 37 (1), 81-87.

Šečerović, Naser (2009) Koestlers Die Herren Call-Girls. In: Weigel, Robert G. (ed.) Arthur Koestler: Ein heller Geinst in dunkler Zeit. Tübingen: Francke, 91-104.

Sperber, Murray A. (1977) Arthur Koestler: A Collection of Critical Essays. Englewood Cliffs, NJ: Prentice-Hall.

Steen, Kirk (2005) Arthur Koestler's Hope in the Unseen: Twentieth-Century Efforts to Retrieve the Spirit of Liberalism. PhD dissertation, Louisiana State University and Agricultural and Mechanical College.

Szívós, Mihály (2006) Koestler Arthur: Tanulmányok és esszék. Budapest: Typotex.

The Koestler Archive. Centre for Research Collections, Edinburgh University Library.

Virginia Quarterly Review (1973) Notes on current books. Virginia Quarterly Review 49 (3), civ-cxxvi.

Williams, Jeffrey J. (2012) The rise of the academic novel. American Literary History 24 (3), 561-589. 
ZÉNÓ VERNYIK graduated from the University of Szeged and Masaryk University and holds a doctorate in Comparative Literature. He is the author of Cities of Saviors: Urban Space in E. E. Cummings 'Complete Poems, 1904-1962 and Peter Ackroyd's Hawksmoor (2015), and the editor (with Dávid Levente Palatinus and Martina Vránová) of Crime and Detection Across Media (forthcoming) and (with Jiř́ Flajšar) of Words into Pictures: E. E. Cummings'Art Across Borders (2007). His most recent research focuses on the oeuvre of British writers of Hungarian origin, but he has also published articles on modern and contemporary American and British literature, Australian cinema, Belgian literature, computer games and detective fiction.

Address: Zénó Vernyik, English Department, Faculty of Science, Humanities and Education, Technical University of Liberec, Studentská 1402/2, 46117 Liberec, Czech Republic. [e-mail: zeno. vernyik@tul.cz] 
